\title{
Sustainability and strategy: A Brazilian integrative review
}

\section{Leandro da Silva Nascimento ${ }^{1, *}$, Fernanda Kalil Steinbruch $^{1}$, Cristina M. Ostermann ${ }^{1}$, Júlio César da Costa Júnior $^{2}$ and Viviane Santos Salazar ${ }^{2}$}

${ }^{1}$ Universidade Federal do Rio Grande do Sul. Programa de Pós-Graduação em Administração. Rua Washington Luiz, 855. Centro Histórico. Porto Alegre-RS, Brasil (CEP 90010-460).*E-mail: lesnasc@gmail.com.

${ }^{2}$ Universidade Federal de Pernambuco. Centro de Ciências Sociais Aplicadas. Av. Prof. Moraes Rego, 1235. Cidade Universitária. Recife-PE, Brasil (CEP 50610-901).

\begin{abstract}
This paper aimed to understand how the fields of strategy and sustainability have been related in papers published in top Brazilian management journals. An integrative review was conducted in July 2019, consisting of a qualitative approach analysis. It was found that there are nine issues that permeate the relation between sustainability and strategy, such as critical analysis, which is present in Brazilian papers but has not been identified in international reviews on this topic. This study highlights the need for critical analysis in the sustainabilitystrategy relationship, a little-explored perspective in both literature and practice. As well, the adoption of organizational theories that can be used to analyze the sustainability-strategy relationship. Seeking to contribute to the scientific advancement of this topic, propositions for future research are presented.
\end{abstract}

Keywords: Sustainability; Strategy; Literature review; Critical approach; Brazil.

Resumo. Sustentabilidade e estratégia: uma revisão integrativa brasileira. Este artigo teve como objetivo compreender como os campos da estratégia e da sustentabilidade têm se relacionado em artigos publicados nos principais periódicos brasileiros de Administração, através de uma revisão integrativa realizada em julho de 2019, consistindo em uma análise de abordagem qualitativa. Constatou-se que existem nove questões que permeiam a relação entre sustentabilidade e estratégia, a análise crítica, que está presente em trabalhos brasileiros, mas não foi identificada em revisões internacionais sobre o tema. Este estudo destaca a necessidade de análise crítica na relação sustentabilidade-estratégia, uma perspectiva pouco explorada na literatura e na prática. Além disso, a adoção de teorias organizacionais que podem ser utilizadas para analisar a relação sustentabilidade-estratégia. Visando a contribuir para o
Received

October 30, 2020

Accept

March 30, 2021

Available online April 13, 2021

Released

April 30, 2021

Open access

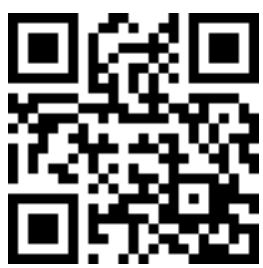

ORCID

D) 0000-0003-0981-1718

Leandro da Silva

Nascimento

D 0000-0001-8059-2752

Fernanda Kalil

Steinbruch

(1) 0000-0001-8399-3519

Cristina M. Ostermann

ISSN 2359-1412/RBGAS-2020-0156/2021/8/18/9/147

Rev. Bras. Gest. Amb. Sustent.

http://revista.ecogestaobrasil.net 
avanço científico do tema, são apresentadas propostas para pesquisas futuras.

Palavras-chave: Sustentabilidade; literatura; Abordagem crítica; Brasil.
D) 0000-0001-8021-4989

Júlio César da Costa

Júnior

Estratégia; Revisão da (ㅇ 0000-0001-7046-3703

\section{Introduction}

Due to the growing visibility of sustainability in the media and in the governmental sphere, it is remarkable the increase and influence of social and environmental concern in the organizational scope (Nascimento and Sousa, 2019). Companies have increasingly placed sustainability on their management agenda (Kiron et al., 2012), developed with organizational goals, missions and values. Thus, there are some studies that preach the need to integrate social and environmental issues into business strategy (e.g., Scherrer et al., 2007; Jin and Bai, 2011; Engert et al., 2016; Baumgartner and Rauter, 2017; Moneva-Abadía et al., 2019) as a way to maximize efficiency and effectiveness. Besides that, the adoption of sustainability in companies requires time (Bansal and Desjardine, 2014), which can corroborate the ideology of their integration into strategy.

Academic publications on strategy and sustainability have increased considerably in recent years (Engert et al., 2016; Marques et al., 2017). However, the relationship between the two fields need further discussion, because the idea of integrating sustainability into strategy can generate a misleading view of their interrelationship, leading to a hierarchical overlap that does not necessarily occur or should occur. In addition, recent literature reviews (e.g., Engert et al., 2016; Marques et al., 2017) sought to analyze the integration of sustainability into strategy, but only papers published in international, non-Brazilian journals, were considered in these studies.

Hence, this study aims to understand how the fields of strategy and sustainability have been related in papers published in top Brazilian management journals. To this end, a qualitative approach analysis was performed using the integrative literature review method (Botelho et al., 2011). The analysis was conducted from a critical-reflexive perspective of the researchers to identify the types of relationships between sustainability and strategy present in Brazilian papers, i.e., whether there is really an integration of sustainability into strategy or there are other forms of relationships between them in the Brazilian context.

Brazil is a relevant research locus because is the thirteenth largest producer of scientific research worldwide (Cross et al., 2017), it has been advancing in the area of organizational studies (Rodrigues and Carrieri, 2001), and it has companies operating in different areas (from agribusiness to creative economy). Also, the analysis of sustainability practices in emerging economies, such as Brazil, has some challenges, mainly due to the emphasis on the country's economic growth (Duarte, 2017) and the natural resources abundance (Huatuco and Ball, 2019) that can be overexploited in the pursuit of such growth.

Thus, this paper is based on the presumption that a concomitant analysis of sustainability and strategy in Brazilian academic context can allow the understanding of economic, environmental, and social factors, promoting a greater comprehension of the specificities' influence of the country's business environment on this relationship. This happens because since sustainable practices are still incipient in Brazil, by advancing the academic studies in this area, it is possible that managers and entrepreneurs pay attention to issues that become relevant in these fields. This means that academic studies can affect 
directly the advancement of management practices in the economy because they support and test best practices, which can help in day-to-day social, environmental, and economic routines of companies.

Also, the Brazilian publication is relevant since the application of sustainability is inherently dependent on the context in which it is applied, considering the social, economic or ecological perspectives (Brown et al., 1987). Thus, the discussion of sustainability can come to an unproductive end without clearly defining the context of social, environmental, and economic concerns (Dovers, 1990). As the sustainability actions required in one location may differ from those required in others, or in different countries, the relationship between sustainability and strategy should consider, above all, the contextual dimension.

Sustainability is a concept that refers to the concern with the quality of a system based on the inseparable integration between environmental, social and economic issues (Murray et al., 2017), characterized by a cross-sectional analysis of the situation experienced in a specific moment. This analysis is operationalized through sustainability indicators (Sehnem et al., 2015; Gonçalves et al., 2019) to obtain quantitative information capable of establishing objectives to be achieved through long-term strategies (Feil and Schreiber, 2017). On the organizational-level, companies contribute to sustainability by systematic management efforts to equally balance environmental, social and economic goals in order to ensure environmental protection and social equity, increasing benefits for as many stakeholders as possible (Klewitz and Hansen, 2014).

Initiatives are being taken to integrate sustainability into organizational business (Scherrer et al., 2007). Companies' commitment to sustainability is discussed in theory and practice, and this relationship should consider the strategic approach to ensure that sustainability is an integral part of business (Engert et al., 2016). But what is strategy? To answer this question, it must be understood that over the years, the concept of strategy has been developed based on different definitions (Khalifa, 2019).

Ronda-Pupo and Guerras-Martin (2011, p. 180) propose that: "the essence of the strategy concept is the dynamics of the firm's relation with its environment for which the necessary actions are taken to achieve its goals and/or to increase performance by means of the rational use of resources", which is assumed for this paper. Other definitions are also intrinsically linked to the economic perspective, especially about the achievement of competitive advantage, leaving social and environmental issues with less priority (Nascimento, 2018).

Historically, studies of strategy have advanced in the organizational field, based on discussions concerning the relationship between strategy, structure, and organizational environment (Ansoff, 1973; Chandler, 1998), between strategy, industry, and competitive dynamics (Porter, 1986, 1991), and about resource-based view (Wernerfelt, 1984; Barney, 1991). These strategic approaches can be related to social, environmental, and economic issues, basing the relationship between sustainability and strategy. The strategy formulation process (deliberate or emergent) proposed by Mintzberg (1978) and the logical incrementalism present in this process (Quinn, 1978) made theoretical advances about the understanding of the bases that underpin strategy formulation in companies. Recent studies show that the formation of sustainability strategies occurs continually between planned and emerging strategies (Neugebauer et al., 2016).

Analyzing the papers on integrating sustainability and strategy, the literature review developed by Engert et al. (2016) demonstrated that this integration was mainly addressed in traditional strategic management research, but was enriched by interdisciplinary know-how from a corporate sustainability perspective. Another literature review addressing the relationship between sustainability and strategy was developed by Marques et al. (2017). Both studies show the existence of a relationship in 
which sustainability actions are used (or even exploited) to support companies' strategic performance.

The indiscriminate use of sustainability practices for merely strategic purposes can lead to limitations on sustainability effectiveness, since "the relationship between these fields needs to consider a level of criticality, as socio-environmental practices can be used as merely strategic resources for purely strategic purposes, preventing the effective development of sustainability" (Nascimento, 2018, p. 186). Broadening the debate, strategy can be understood through three dimensions: process, content and context (De Wit and Meyer, 2010). For these authors, the process is linked to activities; the content corresponds to the results of these activities; and context can be understood as the factors that influence strategic management. These three strategic dimensions can also be analyzed from the sustainability perspective (Baumgartner and Rauter, 2017), which is why the relationship between sustainability and strategy is relevant for business and is approached herein in the Brazilian academic context.

Advancing knowledge about the relationship between sustainability and strategy, from this study results, it was found that nine issues are relevant to analyze the relationship between sustainability and strategy. The study shows that these issues were not addressed in prior literature reviews, such as the critical approach to the relationship between sustainability and strategy. Based on the identified issues, directions for future research are presented.

This study has a potential theoretical contribution, as it allows an interrelational analysis between strategy and sustainability from a critical and contextual perspective, pointing to essential issues of this relationship that are not considered in the management mainstream. It also has a potential practical contribution, as managers working in strategy and sustainability fields can use the findings of this study to boost the adoption of strategies for sustainability.

\section{Methodology}

A qualitative study was conducted using the integrative literature review, which "aims to draw an analysis of the knowledge already built on previous research on a particular topic" (Botelho et al., 2011, p. 127). This method is often used in healthcare and little explored in the management field, despite its proven effectiveness (Botelho et al., 2011). It allows gathering and synthesizing research results on a certain theme, in a systematic and orderly manner, which contributes to the deepening of knowledge about the investigated subject (Mendes et al., 2008).

The review process was composed of a systematic series of steps (Mendes et al., 2008). In the first stage, the terms of search were defined: strategy and sustainability (based on the study purpose) and its related terms, as shown in step 1 of Figure 1 . The related terms were included, as it was perceived that in many papers some of these terms (e.g., sustainable development) are used as synonyms for sustainability. Then, the Brazilian Qualis ranking from Coordenação de Aperfeiçoamento de Pessoal de Nível Superior (CAPES) was accessed in the Sucupira Platform (2013-2016 quadrennium) to define the Brazilian academic journals in the management area that would be consulted. This ranking "is based on a set of formal indicators of organization and editorial process, indexing in databases, and impact factors" (Ferreira, 2015, p. 6). The journals are classified in a stratum of quality: A1 (the highest), A2, B1, B2, B3, B4, B5, and C (the lowest) (CAPES, 2014). 


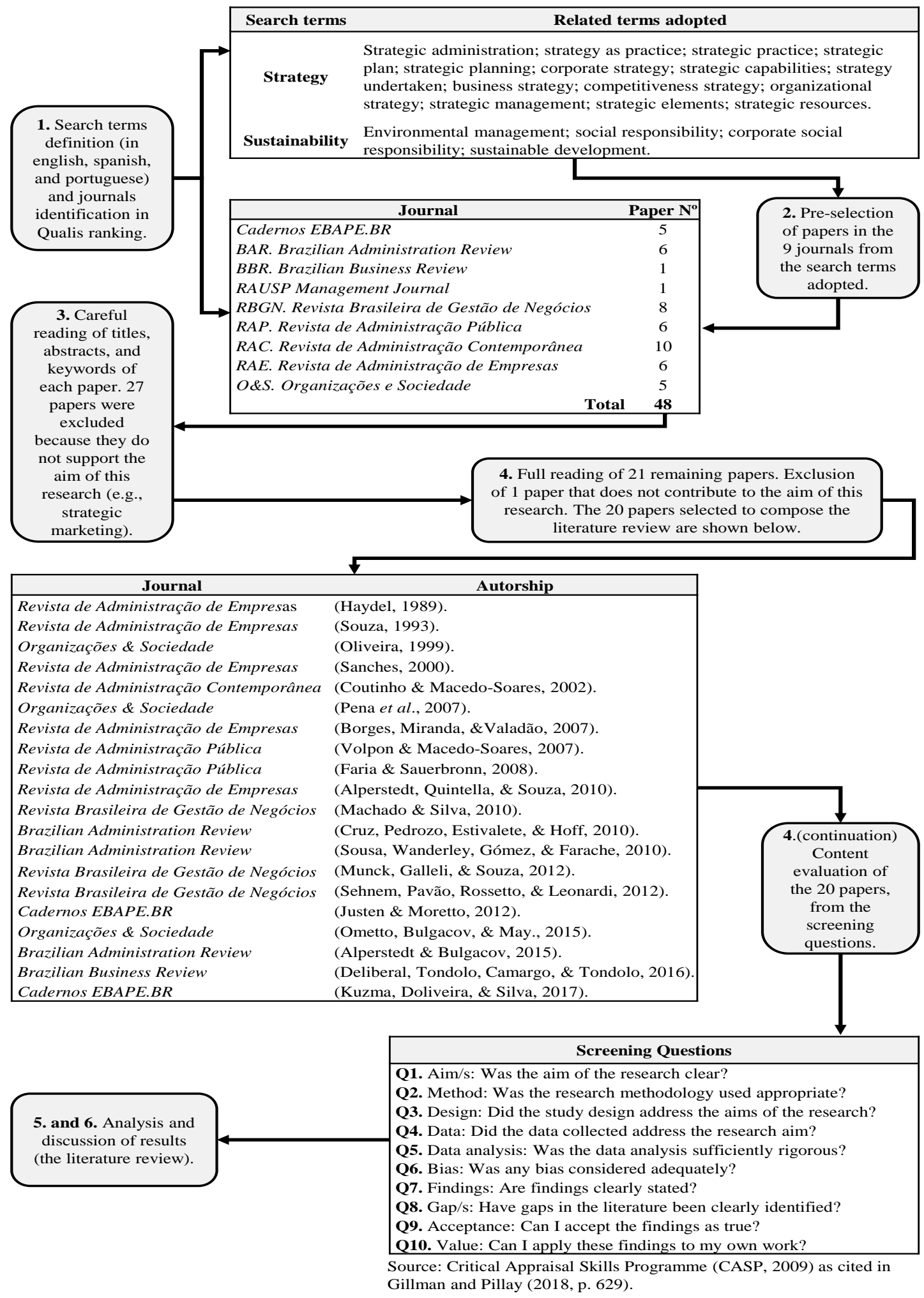

Figure 1. Research design.

The Qualis ranking in the area of Public Administration and Business was used as a selection criterion. Since there are currently no Brazilian management journals classified 
in stratum A1, all journals classified as A2 in the General Management area that cover all topics were selected, excluding those journals that have specific themes within the field of management. Thus, it was reached nine journals, listed in step 1 (Figure 1). The Qualis ranking was adopted because only a few Brazilian journals are indexed in impact factor (Journal Citation Reports [JCR]), which justifies the use of a national ranking.

In the second stage, the websites of each selected journals were accessed and, through the search tool of every journal, it was verified the existence of papers that concomitantly contained the terms 'sustainability' and 'strategy' (or their correlates) in titles, abstracts, or keywords. Thus, papers that simultaneously met these criteria were pre-selected. The pre-selected papers totaled 48, as shown in step 2 (Figure 1), written in Portuguese, English or Spanish. As the period of the papers' publication was not limited, there were considered papers published from the beginning of each journal until July 2019 - date of search.

In the third stage, the titles, abstracts and keywords of each pre-selected paper were carefully read. Papers with terms that did not contribute to the search (e.g., research strategy - method, marketing strategy) were excluded from the analysis. As a result, 27 papers were excluded.

In the fourth stage, it was done the complete reading of the remaining 21 papers. After that, one paper was excluded, as the construction and results of the study did not match the joint analysis of strategy and sustainability. This paper was the only one preselected from RAUSP Management Journal, so no paper from this journal met the inclusion criteria to compose the literature review. The 20 papers selected dated from 1989 to 2017 and are listed in step 4 (Figure 1), with all references given in Table 1.

Table 1. References of the 20 papers analyzed.

\begin{tabular}{|c|c|c|c|}
\hline & Author & Year & Title \\
\hline 1 & Alperstedt and Bulgacov & 2015 & $\begin{array}{l}\text { Environmental management, strategic practices } \\
\text { and práxis: A study in Santa Catarina industrial } \\
\text { companies }\end{array}$ \\
\hline 2 & Alperstedt et al. & 2010 & $\begin{array}{l}\text { Environmental management strategies and their } \\
\text { determinant factors: an institutional analysis }\end{array}$ \\
\hline 3 & Borges & 2007 & $\begin{array}{l}\text { O discurso das fundações corporativas: caminhos } \\
\text { de uma "nova" filantropia? }\end{array}$ \\
\hline 4 & Coutinho and Macedo-Soares & 2002 & $\begin{array}{l}\text { Gestão estratégica com responsabilidade social: } \\
\text { arcabouço analítico para auxiliar sua } \\
\text { implementação em empresas no Brasil }\end{array}$ \\
\hline 5 & Cruz et al. & 2010 & $\begin{array}{l}\text { The influence of transverse CSR structure on } \\
\text { headquarters/subsidiary integration }\end{array}$ \\
\hline 6 & Deliberal et al. & 2016 & $\begin{array}{l}\text { Environmental management as a strategic } \\
\text { capability: a study on the furniture manufacturing } \\
\text { cluster of Southern Brazil }\end{array}$ \\
\hline 7 & Faria and Sauerbronn & 2008 & $\begin{array}{l}\text { Is corporate social responsibility a strategic issue? } \\
\text { A critical approach }\end{array}$ \\
\hline 8 & Haydel & 1989 & $\begin{array}{l}\text { A administração estratégica de programas de } \\
\text { responsabilidade social em empresas } \\
\text { multinacionais: percepções da alta diretoria }\end{array}$ \\
\hline 9 & Justen and Moretto Neto & 2012 & $\begin{array}{l}\text { From economism to the dialogical: the } \\
\text { contributions of the paradigm of deep ecology } \\
\text { and the notion of social management in the theme } \\
\text { of corporate sustainability }\end{array}$ \\
\hline
\end{tabular}


Table 1. Continued.

\begin{tabular}{|l|l|c|l|}
\hline & Author & Year & Title \\
\hline 10 & Kuzma et al. & 2017 & $\begin{array}{l}\text { Skills for organizational sustainability: A } \\
\text { systematic review }\end{array}$ \\
\hline 11 & Machado and Silva & 2010 & $\begin{array}{l}\text { Business strategy and environmental practices: } \\
\text { Evidences on the sugar-alcohol sector }\end{array}$ \\
\hline 12 & Munck et al. & 2012 & $\begin{array}{l}\text { Delivery levels of support competencies to } \\
\text { organizational eco-efficiency: A case study in an } \\
\text { electro-electronics sector industry }\end{array}$ \\
\hline 14 & Oliveira & 1999 & $\begin{array}{l}\text { Indústria petroquímica e a gestão do meio } \\
\text { ambiente }\end{array}$ \\
\hline 15 & Pena et al. & 2015 & $\begin{array}{l}\text { The effectiveness of the strategists of corporate } \\
\text { social responsibility }\end{array}$ \\
\hline 16 & Sanches & 2007 & $\begin{array}{l}\text { Responsabilidade social empresarial e estratégia: } \\
\text { um estudo sobre a gestão do público interno em } \\
\text { duas empresas signatárias do global compact }\end{array}$ \\
\hline 17 & Sehnem et al. & 2012 & $\begin{array}{l}\text { Gestão ambiental proativa } \\
\text { ànação com a implantação de estratégias voltadas } \\
\text { sustentabilidade ambiental: o caso do Grupo } \\
\text { Marfrig Alimentos S.A. }\end{array}$ \\
\hline 19 & Sousa Filho et al. & 2010 & $\begin{array}{l}\text { Strategic corporation social responsibility } \\
\text { management for competitive advantage }\end{array}$ \\
\hline 20 & Volpon and Macedo-Soares & 1993 & $\begin{array}{l}\text { Rumo à prática empresarial sustentável } \\
\text { Alinhamento estratégico da responsabilidade } \\
\text { socioambiental corporativa em empresas que } \\
\text { atuam em redes de relacionamento: resultados de } \\
\text { pesquisa na Petrobras }\end{array}$ \\
\hline
\end{tabular}

These papers were critically analyzed, based on the questions presented in step 4 (continuation) of Figure 1. Even though these questions were developed in the health area, they present a solid basis for the quality analysis of the research, being useful for the evaluation of papers in other knowledge fields, including management. The fifth and sixth stages consisted of the analysis and interpretation of the results, and are presented together in the next section. It is relevant to emphasize that the analysis was conducted from a critical-reflexive perspective of the researchers, where triangulation was adopted to compare and discuss individual results in order to generate a common understanding.

\section{Results and discussion}

This section starts with an evaluation of the Brazilian papers through the critical screening questions presented in step 4 (continuation) of Figure 1 . This allows the acknowledgement of the papers' quality level analyzed. Then, a content analysis was conducted, and the main issues identified in the relationship between sustainability and strategy in the Brazilian papers are presented.

\section{Overview of sustainability-strategy publications in Brazil (1989-2017)}

In general, the papers analyzed were characterized by quantitative, qualitative and mixed approaches and differ in the directions and research methods used, being mostly empirical papers. Studies presented in its majority the analysis of Brazilian companies, such as the works of Oliveira (1999), Borges et al. (2007), Pena et al. (2007), Volpon and Macedo-Soares (2007), Alperstedt et al. (2010), Cruz et al. (2010), Machado and Silva 
(2010), Munck et al. (2012), Sehnem et al. (2012), Alperstedt and Bulgacov (2015), and Ometto et al. (2015).

It was possible to identify that some authors use social responsibility as a concept equivalent to sustainability, just as sustainability and sustainable development are indistinctly defined (Justen and Moretto Neto, 2012). Therefore, the conception of social responsibility is usually associated with sustainable development and sustainability (Ometto et al., 2015). Given the lack of conceptual attention in some Brazilian papers on aspects that differentiate sustainability from other concepts, an indistinct analysis of the various concepts was adopted. This indistinct analysis was adopted because even if the papers do not represent sustainability in its central character as proposed by Feil and Schreiber (2017), they address sustainability issues by defining them as social responsibility, sustainable development or address issues specific to just one dimension of sustainability - such as environmental management.

\section{Identified issues in the relationship between sustainability and strategy}

The papers were explored based on a thematic/categorical content analysis (Bardin, 2016), and after the analysis and the interpretation of the results, the literature review showed the existence of nine essential issues (which are the analysis categories) that support the relationship between strategy and sustainability: 1) Change process; 2) Specialized managers; 3) Process of strategy formulation; 4) Strategic sustainability networks; 5) Social and environmental focus; 6) Application and evaluation tools; 7) Contextual influences; 8) Proactivity and reactivity; and 9) Critical analysis. The issues contextual influences and critical analysis were defined from the theoretical background and sustained in the analysis, while the other issues emerged from the data analysis. Figure 2 presents the issues identified.

These issues emerged when reading each paper, and the recurrence of certain themes allowed the grouping of ideas presented and, thus, the recurring arguments in more than one paper were grouped by researchers in nine categories, according to the potential of these for the relational analysis proposed in this study. The issues are interconnected in the activity process of organizations that relate sustainability and strategy, and the last one (Critical analysis) demonstrated a core value in the analysis of the relationship between sustainability and strategy, permeating all other issues. The identified issues are explored next.

Change process. Considering social and environmental issues, new attitudes in the business operation and in the form of organization are required, which drives continuous change (Sanches, 2000). Concerns about social responsibility lead companies to implement changes that must be aligned with the company's strategy (Coutinho and Macedo-Soares, 2002). These authors state that sometimes the company must start a change of values in search of an appropriate culture to the quality of life and to the participation of its members so that, further, they can implement a change on social responsibility in a strategic way.

From Alperstedt and Bulgacov (2015, p. 290) perspective, "the discourse of strategy refers not only to the idiosyncratic product of a certain corporate culture, but as part of considerable social change with effects that go beyond the organization". For them, social practices can be analyzed from a strategic perspective (strategy as practice) and from an environmental perspective, considering that such practices can be cognitive, behavioral, procedural, discursive, motivational and physical, being possible to state that "the organizations strive to improve their management practices in strategic ways that help them to respond to social and environmental demands" (Kuzma et al., 2017, p. 430), which occurs through the process of organizational change. 


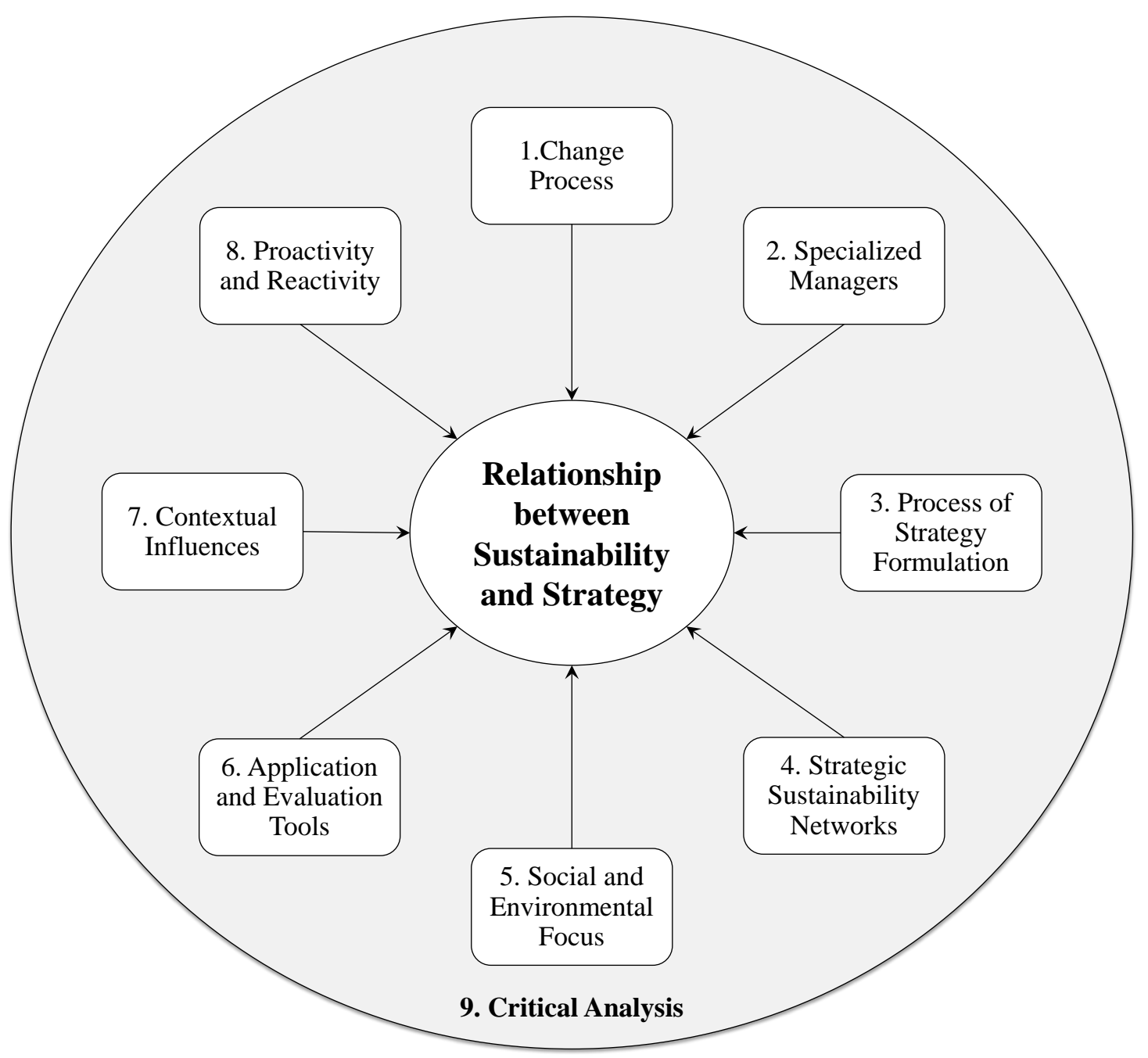

Figure 2. Identified issues in the sustainability-strategy relationship.

Specialized managers. In some companies, it is identified the concern about the creation of specific departments that deal with environmental management, resulting in a modification of the hierarchical structure (Oliveira, 1999). Likewise, Sanches (2000) presents the need for new managerial talents to deal with environmental dimensions. However, many companies do not have the position of environmental manager in the organization chart, showing that the lack of specialized professionals in the subject is a deadlock (Machado and Silva, 2010).

It is considered that managers need to be directly involved in the formation process of organizational culture directed to the environmental strategy and that employees need to know the importance of social and environmental issues for decision making and for the organization's strategy (Sehnem et al., 2012; Ometto et al., 2015). Therefore, organization's employees are the main source of (intangible) resources, requiring greater attention for the correct adoption of social and environmental practices in a strategic way (Sehnem et al., 2012), and showing that organizations should have specialized managers in strategy and sustainability. 
Process of strategy formulation. Multinational leaders believe that corporate social responsibility is critical to achieve global objectives through long-term plans (Haydel, 1989; Cruz et al., 2010). When considering a long-term strategic vision, social responsibility is part of strategic planning (Pena et al., 2007; Machado and Silva, 2010), and is an efficient and effective way to address social and environmental problems and needs (Sanches, 2000). However, Machado and Silva (2010) identified a company that uses incremental practices combined with planning in the formation of its strategies (Mintzberg, 1978), also corroborating to the logical incrementalism (Quinn, 1978) which advocates the formation of certain strategies as a learning process. Thus, sustainabilityrelated strategies can be deliberated (e.g., strategic planning) or emerging (Neugebauer et al., 2016).

Strategic sustainability networks. To sustain competitive advantage, companies seek to intensify alliances and develop networks, but social responsibility actions need to be aligned with all companies' strategies that compose these alliances or networks (Volpon and Macedo-Soares, 2007). Some companies are concerned about doing business only with organizations that are environmentally and socially responsible (Machado and Silva, 2010), contributing to broaden sustainability actions strategically throughout the value chain and beyond their local or regional operations.

Social and environmental focus. For some companies, it is important to focus on social aspects (Haydel, 1989), highlighting actions in favor of education and health (Borges et al., 2007). In addition to social issues, environmental protection has become relevant in business strategies, being an important element of strategy, management practice and technological innovation (Souza, 1993; Oliveira, 1999). In Brazilian business environment, social responsibility is gaining prominence, but its motivations are of different natures (Coutinho and Macedo-Soares, 2002), since companies position themselves in different ways regarding social or environmental responsibility (Volpon and Macedo-Soares, 2007).

The environmental, social and economic dimensions of sustainability are subsystems that must be developed in a balanced manner (Munck et al., 2012). However, most of the papers analyzed do not follow this guideline and generally deal with social and environmental aspects, not focusing on the economic dimension of sustainability. Therefore, the focus on social and environmental issues emerges as a way to compensate the traditional lack of attention of these issues by companies, because the functionalist thinking argues that the greatest contribution a company can make to society is related to economic prosperity (Porter and Kramer, 2006).

Application and evaluation tools. Throughout the analysis, it was identified that there is a deficiency in relation to the instruments used to implement and measure the effectiveness of strategic actions for sustainability. Even though there are few measures to verify the environmental performance in companies, it is important to focus on the construction of techniques and tools to make this assessment (Machado and Silva, 2010).

Munck et al. (2012) proposed a model for measuring the level of business ecoefficiency from the identification of the delivery levels of organizational skills supporting ecoefficiency. Coutinho and Macedo-Soares (2002) proposed a model that allows the analysis of the implementation strategic adequacy of actions aiming social responsibility. Considering the strategic character of sustainability, it is noteworthy that "evaluation techniques seem to be the weakest point of the strategic management process" (Haydel 1989, p. 17). Thus, the lack of tools to implement and measure sustainability makes it impossible to control or improve social, environmental and economic actions. 
Contextual influences. The context has a strong influence on the positioning and course of actions that companies perform in their social systems. In an interaction analysis between multinational units, there is little information consultation between headquarters and their subsidiaries in other countries, which interferes the definition of social goals (Haydel, 1989). Likewise, Souza (1993, p. 50) states that "environmental protection measures are being awakened, in some cases, by multinationals, which transfer to the Brazilian headquarters the guidelines outlined in their central offices".

It is noticeable the lack of understanding of the headquarters about the endogenous conditions and situations experienced by the subsidiaries in their contexts (social, cultural, political and environmental), with only a replication of actions from one context to another, making it difficult to carry out socio-environmental actions, since it is necessary to consider global needs as well as local conditions of the subsidiaries in the social responsibility actions undertaken by the headquarters (Cruz et al., 2010).

Historically, Brazilian companies do not give the appropriate importance to the environmental dimension and its impacts on their business activities, which hinders the development of adequate responses (Sanches, 2000). However, they are increasingly concerned about social responsibility, so that the environmental dimension now includes an important factor in their strategic agendas (Coutinho and Macedo-Soares, 2002). Both organizational and contextual characteristics are essential for understanding the course of action to be taken for sustainability, as social and environmental initiatives can alter contextual competitive relationships, enabling increased quality of relationships in business environments (Sousa Filho et al., 2010).

The contextual approach in studies on corporate sustainability and strategy can be analyzed through some approaches and organizational theories, namely: agency theory; firm theory; resource-based view; institutional theory; and stakeholder theory (Borges et al., 2007). Thus, it is possible to identify that the actions of competitors also influence the company's behavior by institutionalizing some practices (Machado and Silva, 2010), and according to Faria and Sauerbronn (2008, p. 25), "in the context of globalization, some researchers began to explore institutional theory to deal with corporate social responsibility issues under a strategic approach."

Machado and Silva (2010, p. 408) state that "the adoption of an environmental approach, less than a voluntary decision of the company, must be understood as a decision permeated by its own contingencies and contexts", and sustainability can be treated as a strategy to adapt to the environment (Pena et al., 2007). In contingency theory, the organization is seen as adaptable to the environment in its specific context, which was revealed in the papers analyzed in this study.

Proactivity and reactivity. The social responsibility actions found in multinationals are more reactive than proactive (Haydel, 1989), since they adopt policies that meet minimum external requirements (Oliveira, 1999; Alperstedt and Bullgacov, 2015). This is because "many managers still respond to environmental issues and therefore understand them as expenses without seeing returns through environmental actions" (Deliberal et al., 2016, p. 123). On the other hand, it can also be seen that companies are beginning to glimpse business opportunities through social responsibility practices - initiating proactive actions (Coutinho and Macedo-Soares, 2002; Alperstedt et al., 2010; Machado and Silva, 2010; Sanches, 2000), because a preventive action costs less and is more efficient (Souza, 1993).

Critical analysis. During the analysis, it was found that environmental management is not yet being dealt with a strategic bias by companies (Alperstedt and Bulgacov, 2015), being the relationship between environmental management and strategy still very incipient and requiring greater alignment (Machado and Silva, 2010). For Kuzma 
et al. (2017), sustainability should not be analyzed just as a discourse on ecology and economy, but as an ideological and political discourse. Thus, there is a separation between discourse and practice about environmental actions in companies (Alperstedt et al., 2010).

Kuzma et al. (2017, p. 442) identified that "the discourse that involves the generation of organizational competencies focused on sustainability actions is far from practical reality and does not always produce effects that impact the operational dimension of organizations". Thus, it is necessary to develop critical reflexivity about the characteristics of the strategy area, but such questions have not been valued by some researchers who consider the approach of social responsibility and strategy a tactic that large corporations use to regain their legitimacy and reputation (Faria and Sauerbronn, 2008).

Moreover, the strategic approach usually reproduces the models developed in the United States of America (USA) without questioning the neutrality or historical background of the area (Faria and Sauerbronn, 2008). This indiscriminate acceptance of foreign models tends to impoverish the cultural and historical variety of Brazilian reality (Justen and Moretto Neto, 2012). Similarly, Ramos (1965) criticizes the indiscriminate assimilation of theories coming from other countries without an analysis and contextualization for the considered country.

Lastly, "strategically planning for sustainability involves a new critical, reflective dialogical and communicative view in the relationships between man and man; man and organization; environment and organization; and environment and man" (Justen and Moretto Neto, 2012, p. 748), in a way that the approach of the strategy area to sustainability also contemplates the public dimension, in which social issues do not become mere strategic and political resources for the capitalist view of large corporations (Faria and Sauerbronn, 2008).

\section{Correlation with prior reviews}

Two recent literature reviews analyzed the relationship between sustainability and strategy. The first (Marques et al., 2017) identifies three intellectual bases that influenced the study of strategy and sustainability: (i) the relationship between sustainability and competitiveness; (ii) the relationship between resources/capabilities for competitive advantage with sustainability; (iii) the environmental influence on competitive advantage considering sustainability. The second (Engert et al., 2016) brings the integration of sustainability into strategy based on three essential areas: (i) organizational influences; (ii) internal and external conductors; and (iii) supporting factors. One of the components of the second area proposed by Engert et al. (2016) is the competitive advantage, also highlighted by Marques et al. (2017).

The findings of prior reviews were related to those of the present research, which allowed to verify that the results related to Brazilian publications are not distant from the results of international publications, based on the relationship between sustainability and competitive advantage as one of the issues cited in Brazilian papers (e.g., Souza, 1993; Sanches, 2000; Coutinho and Macedo-Soares, 2002; Pena et al., 2007; Volpon and Macedo-Soares, 2007; Sousa Filho et al., 2010; Munck et al., 2012; Alperstedt and Bulgacov, 2015; Ometto et al., 2015; Deliberal et al., 2016; Kuzma et al., 2017).

Regarding contextual aspects, unlike international results, the findings of Brazilian papers (e.g., Haydel, 1989; Souza, 1993; Sanches, 2000; Coutinho and Macedo-Soares, 2002; Borges et al., 2007; Pena et al., 2007; Faria and Sauerbronn, 2008; Cruz et al., 2010; Machado and Silva, 2010; Alperstedt and Bullgacov, 2015) deepen the discussion on contextual aspects that influence the relationship between sustainability and strategy, focusing on discussions about organizational theories and critical perspective that were not cited in these prior reviews. 


\section{Final remarks}

The academic production of Brazilian management journals with high academic relevance has related the fields of sustainability and strategy based on nine issues (Figure 2 ). All issues are relevant to analyze and formulate relationships between sustainability and strategy. For example, the development of strategies for sustainability needs to consider the process of strategy formulation (Issue 3), which ensures greater effectiveness of the processes and results. As well, the effectiveness of these strategies depends on the impetus given to these areas by companies, which can be maximized by the existence of specialized managers in both the strategy and sustainability fields (Issue 2).

Another example is related to the expansion of practices beyond the company, i.e., as much efficient and effective the sustainability strategies developed in a company may be, they will only generate greater socio-environmental impacts if the companies' business partners also adopt sustainability practices strategically. Thus, strategic sustainability networks (Issue 4) are essential for this purpose and must be considered in the development of the sustainability-strategy relationship.

All the issues presented herein are relevant and necessary for the development of relationships between sustainability and strategy and can be interconnected with each other. In this sense, for instance, the development of strategic sustainability networks (Issue 4) needs to consider a critical analysis (Issue 9) of these networks, in order to determine if the partners really contribute to sustainability as stated in their speeches. Hence, besides these issues influence the development of relationships between sustainability and strategy, they can also be mutually influential, requiring greater attention from companies when dealing with sustainability practices in a strategic way.

The ninth issue (Critical analysis) plays a central role, demonstrating the critical consideration in Brazilian scientific production about the relationship between sustainability and strategy in organizations. This critical perspective was not identified in prior reviews developed by Engert et al. (2016) and Marques et al. (2017). Thus, it suggests that the relationship between sustainability and strategy requires a critical analysis as a core value, in a way that sustainability is not disseminated as a mere fallacious discourse and incompatible with the adopted practices in organizations.

From the identification of this critical approach in the Brazilian context, it can be inferred that this critical perspective has a strong spread in management studies in Brazil as a whole. This greater concern with theories and phenomena analyzed has been highlighted since the works of Ramos (1965). Since then, Brazilian researchers in the social sciences have sought to analyze the variety of social phenomena based on a higher level of criticality. This may justify the reason why Brazilian papers present critical perspectives on the relationship between sustainability and strategy that are not pointed out in other international studies, such as that of Engert et al. (2016) and Marques et al. (2017).

Another finding of this paper that was not identified in these international reviews is the consideration of the contextual influence on the relationship between sustainability and strategy, mainly about organizational theories. For instance, the Brazilian papers analyzed here are based on contingency theory and institutional theory as ways of better understanding the sustainability-strategy relationship from the analyzed context. Thus, it can be inferred that the adoption of organizational theories may enable a better understanding of the social, environmental, and economic phenomena that permeate the relationship between sustainability and strategy, and should be used in research on this topic.

Besides these findings, it is possible to affirm that the relational publication between sustainability and strategy in the top Brazilian management journals has decreased. This is evident because 4 papers published between 1989 and 2000 were 
identified, 9 papers were published between 2002 and 2010 ( 4 only in 2010), 3 papers in 2012, 2 papers in 2015, and only 1 paper in 2016 and 1 in 2017. After that, no papers were published until June 2019 - search carried out. Thus, while the international publication on this theme has increased in recent years (Engert et al., 2016; Marques et al., 2017), it seems that Brazilian research has taken an opposite direction, in which the theme seems to be no longer intriguing for the Brazilian context. About this, it can be inferred that, with the advent of the need to expand the Brazilian publication for beyond the national scope, it is possible that researchers on this topic are publishing in international, non-Brazilian journals.

Table 2. Propositions for future research.

\begin{tabular}{|c|c|}
\hline Identified issues & Propositions \\
\hline Change Process & $\begin{array}{l}\text { 1. Understand the level of change (both internal and external) } \\
\text { that companies adopt to develop an effective relationship } \\
\text { between sustainability and strategy. }\end{array}$ \\
\hline Specialized managers & $\begin{array}{l}\text { 2. Verify the creation of positions for managers specialized in } \\
\text { sustainability in companies and what previous knowledge and } \\
\text { skills are required of these professionals. } \\
\text { 3. Analyze the level of decision making of these managers } \\
\text { specialized in sustainability and how they can strategically } \\
\text { interfere in the actions of other sectors of an organization. }\end{array}$ \\
\hline $\begin{array}{l}\text { Contextual influences } \\
\text { Process of strategy formulation } \\
\text { Proactivity and reactivity }\end{array}$ & $\begin{array}{l}\text { 4. Analyze the relationship between contextual influences and } \\
\text { their impacts on the process of formulating sustainability } \\
\text { strategies, checking whether they tend to be proactive or } \\
\text { reactive as a function of contextual influence. }\end{array}$ \\
\hline sustainability & $\begin{array}{l}\text { 5. Identify the occurrence of networks or strategic alliances for } \\
\text { sustainability in both large corporations and small enterprises. } \\
\text { 6. Verify how these strategic relationships are formed and what } \\
\text { mechanisms companies use to ensure the sustainability } \\
\text { requirements were met by business partners. }\end{array}$ \\
\hline Application and evaluation tools & $\begin{array}{l}\text { 7. Analyze the main tools of sustainability implementation and } \\
\text { assessment in organizations and how these tools can be } \\
\text { replicated by companies in different contexts and different } \\
\text { industries. }\end{array}$ \\
\hline $\begin{array}{l}\text { Social and environmental focus } \\
\text { Contextual influences }\end{array}$ & $\begin{array}{l}\text { 8. Analyze whether the focus on social or environmental actions } \\
\text { derives from the specific sector of companies or whether } \\
\text { organizations in the same sector in different regional contexts } \\
\text { can focus on other actions for sustainability, checking whether } \\
\text { the focus on the social or environmental dimension is derived } \\
\text { from the local contextual influences and not from the industry } \\
\text { in which the company operates. }\end{array}$ \\
\hline Critical analysis & $\begin{array}{l}\text { 9. Evaluate the occurrence of critical analysis about the } \\
\text { relationship between sustainability and strategy in the } \\
\text { companies' performance, since this position is theoretically } \\
\text { discussed by scholars, being necessary to empirically verify if } \\
\text { companies pay attention to these issues when adopting } \\
\text { sustainability practices strategically. }\end{array}$ \\
\hline
\end{tabular}

Furthermore, it was noticed that some journals published more papers on this theme than others, which may delimit possible outlets for researchers interested in publishing in Brazil. The journal with the largest number of publications was the Revista 
de Administração de Empresas with 5 papers, followed by Brazilian Administration Review, Organizações and Sociedade, and Revista Brasileira de Gestão de Negócios with 3 papers each, Cadernos EBAPE.BR and Revista de Administração Pública with 2 papers each, and Brazilian Business Review and Revista de Administração Contemporânea with 1 paper each.

Based on the nine issues identified, some questions raised, and Table 2 presents propositions that can be analyzed in future research, as a form of theoretical and practical improvement of the relationship between sustainability and strategy. These propositions point to gaps that can be approached to advance the relational knowledge between sustainability and strategy from different perspectives. These directions for future research can occur both in developing countries (such as Brazil) and in developed countries. As well, companies of different sizes and segments can be analyzed, which can demonstrate the existence of new phenomena not yet identified in this field.

Based on the results, scholars in strategy and sustainability fields will be able to broaden the knowledge about the bases that underlie the relationship between these fields in a developing country, with their own contextual aspects. Still on the academic field, it is necessary to emphasize that the Brazilian papers analyzed demonstrate the lack of conceptual delimitation by scholars about sustainability, because in many papers, sustainability is used as a synonym of sustainable development and/or corporate social responsibility. Although many papers focused on sustainability, few include a definition of sustainability in the theoretical foundation (Salas-Zapata et al., 2017). Hence, it is expected that works about sustainability specify the definition on which they are based to conduct the research (Salas-Zapata and Ortiz Muñoz, 2019), which enables readers to better understand the aspects inherent in the concept.

From a practical perspective, organizational managers can deepen their knowledge on how to improve the relationship between sustainability and strategy in the organizational environment. This allows the improvement of sustainability practices in a sustainable way, especially through the issues exposed in this study.

Finally, it is noteworthy that the adoption of a qualitative approach in conducting this review generated certain limitations, such as the lack of the analysis of bibliometric issues (e.g., citations and co-citations), which could be performed in a quantitative approach. The focus on Brazilian management journals qualified as A2 can be another limitation, since the number of papers found was low and most of these were published more than five years ago. Thus, the expansion to journals of other Qualis ranking strata could increase the number of papers and, consequently, deepen the discussion. In addition to these limitations, the central issue (Critical analysis) identified in this study was developed based on the authors' perspectives of the papers analyzed in this review, and there is no empirical evidence of the consideration of this critical perspective by managers in conducting business.

\section{References}

Alperstedt, G. D.; Bulgacov, S. Environmental management, strategic practices and práxis: A study in Santa Catarina industrial companies. Brazilian Administration Review, v. 12, p. 288-308, 2015. https://doi.org/10.1590/1807-7692bar2015150016

Alperstedt, G. D.; Quintella, R. H.; Souza, R. L. Environmental management strategies and their determinant factors: An institutional analysis. Revista de Administração de Empresas, v. 50, p. 170-186, 2010. https://doi.org/10.1590/S0034-75902010000200004

Ansoff, H. I. Toward a strategic theory of the firm. In Ansoff, H. I. (Ed.). Business strategy. Great Britain: Penguin Books, 1973. p. 11-40. 
Bansal, P.; Desjardine, M. R. Business sustainability: It is about time. Strategic Organization, v. 12, p. 70-78, 2014. https://doi.org/10.1177/1476127013520265

Bardin, L. Análise de conteúdo. São Paulo: Edições 70, 2016.

Barney, J. Firm resources and sustained competitive advantage. Journal of Management, v. 17, p. 99-120, 1991.

Baumgartner, R. J.; Rauter, R. Strategic perspectives of corporate sustainability management to develop a sustainable organization. Journal of Cleaner Production, v. 140, p. 81-92, 2017. https://doi.org/10.1016/j.jclepro.2016.04.146

Borges, J. F.; Miranda, R.; Valadão Jr., V. M. O discurso das fundações corporativas: caminhos de uma "nova" filantropia? Revista de Administração de Empresas, v. 47, p. 101-115, 2007. https://doi.org/10.1590/S0034-75902007000400009

Botelho, L. L. R.; Cunha, C. C. A.; Macedo, M. The integrative review method in organizational studies. Gestão e Sociedade, v. 5, p.121-136, 2011. https://doi.org/10.21171/ges.v5i11.1220

Brown, B. J.; Hanson, M. E.; Liverman, D. M.; Merideth Jr., R. W. Global sustainability: Toward definition. Environmental Management, v. 11, p. 713-719, 1987. https://doi.org/10.1007/BF01867238

CAPES - Coordenação de Aperfeiçoamento de Pessoal de Nível Superior. Qualis Periódicos e classificação de produção intelectual. 2014. Available from: $<$ https://www.capes.gov.br/avaliacao/instrumentos-de-apoio/qualis-periodicos-eclassificacao-de-producao-intelectual>. Accessed on: Mar. 15, 2020.

Chandler, A. D. Introdução a strategy and structure. In: McCrawn, T. K. (Org.). Ensaios para uma teoria histórica da grande empresa. Rio de Janeiro: Fundação Getúlio Vargas, 1998. p. 119-140.

Coutinho, R. B. G.; Macedo-Soares, T. D. L. V. A. Gestão estratégica com responsabilidade social: arcabouço analítico para auxiliar sua implementação em empresas no Brasil. Revista de Administração Contemporânea, v. 6, p. 75-96, 2002. https://doi.org/10.1590/S1415-65552002000300005

Cross, D.; Thomson, S.; Sibclair, A. Research in Brazil: A report for CAPES by Clarivate analytics. 2017. Available from: <http://www.capes.gov.br/images/stories/download/ diversos/17012018-CAPES-InCitesReport-Final.pdf>. Accessed on: Mar. 15, 2020.

Cruz, L. B.; Pedrozo, E. A.; Estivalete, V. F. B.; Hoff, D. N. The influence of transverse CSR structure on headquarters/subsidiary integration. Brazilian Administration Review, v. 7, p. 310-324, 2010. https://doi.org/10.1590/S1807-76922010000300007

De Wit, B.; Meyer, R. Strategy: Process, content, context: An international perspective. 4. ed. Rome: Thomson, 2010.

Deliberal, J. P.; Tondolo, V. A. G.; Camargo, M. E.; Tondolo, R. R. P. Environmental management as a strategic capability: A study on the furniture manufacturing cluster of Southern Brazil. Brazilian Business Review, v. 13, p. 118-140, 2016. https://doi.org/10.15728/bbr.2016.13.4.6

Dovers, S. R. Sustainability in context: An Australian perspective. Environmental Management, v. 14, p. 297-305, 1990. https://doi.org/10.1007/BF02394197

Duarte, F. P. Sustainability learning challenges in a Brazilian government organization. International Journal of Organizational Analysis, v. 25, p. 562-576, 2017. https://doi.org/10.1108/IJOA-02-2015-0842 
Engert, S.; Rauter, R.; Baumgartner, R. J. Exploring the integration of corporate sustainability into strategic management: A literature review. Journal of Cleaner Production, v. 112, p. 2833-2850, 2016. https://doi.org/10.1016/j.jclepro.2015.08.031

Faria, A.; Sauerbronn, F. F. Is corporate social responsibility a strategic issue? A critical approach. Revista de Administração Pública, v. 42, p. 07-33, 2008. https://doi.org/10.1590/S0034-76122008000100002

Feil, A. A.; Schreiber, D. Sustainability and sustainable development: Unraveling overlays and scope of their meanings. Cadernos EBAPE.BR, v. 14, p. 667-681, 2017. https://doi.org/10.1590/1679-395157473

Ferreira, M. P. Journals and journal rankings in management. Revista Pensamento $\begin{array}{lllll}\text { Contemporâneo em } & \text { Administração, } & \text { v. 9, } & \text { p. 1-16, }\end{array}$ https://doi.org/10.12712/rpca.v9i2.502

Geissdoerfer, M.; Savaget, P.; Bocken, N. M. P.; Jan, E. The Circular Economy: A new sustainability paradigm? Journal of Cleaner Production, v. 143, p. 757-768, 2017. https://doi.org/10.1016/j.jclepro.2016.12.048

Gillman, M.; Pillay, M. An integrative literature review: What are the barriers that stop organisations from learning the lessons highlighted in serious incident investigations? In: Arezes, P. (Ed.). Advances in safety management and human factors. Cham: Springer, 2018. (Advances in Intelligent Systems and Computing, v. 604). https://doi.org/10.1007/978-3-319-60525-8_63

Gonçalves, P. V. S.; Tavares, P. A.; Beltrão, N. E. S.; Ferreira Filho, H. R. Logística reversa de pneus inservíveis: diagnóstico situacional com aplicação de matriz de indicadores de sustentabilidade nos Municípios de Belém e Ananindeua, Pará. Navus - Revista de Gestão e Tecnologia, v. 9, p. 165-181, 2019. https://doi.org/10.22279/navus.2019.v9n1.p165181.806

Haydel, B. F. A administração estratégica de programas de responsabilidade social em empresas multinacionais: percepções da alta diretoria. Revista de Administração de Empresas, v. 29, p. 5-29, 1989.

Huatuco, L. H.; Ball, P. D. The quest for achieving United Nations sustainability development goals (SDGs): Infrastructure and innovation for responsible production and $\begin{array}{lllll}\text { consumption. RAUSP Management Journal, v. 54, p.357-362, } 2019 . & \end{array}$ https://doi.org/10.1108/RAUSP-04-2019-0068

Jin, B. Z.; Bai, Y. Sustainable development and long-term strategic management embedding a long-term strategic management system into medium and long-term planning. World Futures Review, v. 3, p. 49-69, 2011. https://doi.org/10.1177/194675671100300208

Justen, C. E.; Moretto Neto, L. From economism to the dialogical: The contributions of the paradigm of Deep Ecology and the notion of social management in the theme of corporate $\begin{array}{lllll}\text { sustainability. } & \text { Cadernos } & \text { EBAPE.BR, } & \text { v. 10, } & \text { p.736-750, }\end{array}$ https://doi.org/10.1590/S1679-39512012000300015

Khalifa, A. Strategy: Restoring the lost meaning. Journal of Strategy and Management, v. 13, p. 128-143, 2019. https://doi.org/10.1108/JSMA-09-2019-0158

Kiron, D.; Kruschwitz, N.; Haanaes, K.; Velken, I. S. Sustainability nears a tipping point. MIT Sloan Management Review, v. 28, p. 69-74, 2012.

Klewitz, J.; Hansen, E. G. Sustainability-oriented innovation of SMEs: A systematic review. $\begin{array}{lllll}\text { Journal of cleaner production, } & \text { v. } 65, & \text { p. } 57-75,\end{array}$ https://doi.org/10.1016/j.jclepro.2013.07.017 
Korhonen, J.; Honkasalo, A.; Seppälä, J. Circular Economy: The concept and its limitations. $\begin{array}{llll}\text { Ecological } & \text { Economics, } & \text { v. 143, } 37-46, & \text { p. }\end{array}$ https://doi.org/10.1016/j.ecolecon.2017.06.041

Kuzma, E. L.; Doliveira, L. S. D.; Silva, A. Q. Skills for organizational sustainability: A systematic review. Cadernos EBAPE.BR, v. 15, p. 428-444, 2017. https://doi.org/10.1590/1679-395160726

Machado, A. G. C.; Silva, J. C. Business strategy and environmental practices: Evidences on the sugar-alcohol sector. Revista Brasileira de Gestão de Negócios, v. 12, p. 405-424, 2010. https://doi.org/10.7819/rbgn.v12i37.730

Marques, L. S.; Kniess, C. T.; Meira, S. R.; Ruiz, M. S. Research in strategy and sustainability: Proposal of a research agenda from a bibliometric study. Revista Ibero-Americana de Estratégia, v. 16, p. 5-21, 2017.

Mendes, K. D. S.; Silveira, R. C. C. P.; Galvão, C. M. Integrative literature review: A research method to incorporate evidence in health care and nursing. Texto Contexto Enfermagem, $\quad$ v. 17, p. 758-764, 2018. https://doi.org/10.1590/S010407072008000400018

Mintzberg, H. Patterns in strategy formation. Management Science, v. 24, p. 934-948, 1978.

Moneva-Abadía, J. M.; Gallardo-Vázquez, D.; Sánchez-Hernández, M. I. Corporate social responsibility as a strategic opportunity for small firms during economic crises. Journal of Small Business Management, v. 57, p.172-199, 2019. https://doi.org/10.1111/ jsbm. 12450

Munck, L.; Galleli, B.; Souza, R. B. Delivery levels of support competencies to organizational eco-efficiency: A case study in an electro-electronics sector industry. Revista Brasileira de Gestão de Negócios, v. 14, p. 274-292, 2012. https://doi.org/10.7819/ rbgn.v14i44.948

Murray, A.; Skene, K.; Haynes, K. The Circular Economy: An interdisciplinary exploration of the concept and application in a global context. Journal of Business Ethics, v. 140, p. 369380, 2017. https://doi.org/10.1007/s10551-015-2693-2

Nascimento, L. S. Uma reflexão acerca da relação entre sustentabilidade e estratégia organizacional. In: Andrade, D. F. (Ed.). Sustentabilidade e responsabilidade social em foco. Belo Horizonte: Poisson, 2018. v. 5. p. 186-197.

Nascimento, L. S.; Sousa Jr., J. H. Relacionando capital intelectual, gestão do conhecimento e sustentabilidade: um modelo conceitual. Navus - Revista de Gestão e Tecnologia, v. 9, p. 92-104, 2019. https://doi.org/10.22279/navus.2019.v9n2.p92-104.867

Neugebauer, F.; Figge, F.; Hahn, T. Planned or emergent strategy making? Exploring the formation of corporate sustainability strategies. Business Strategy and the Environment, v. 25, p. 323-336, 2016. https://doi.org/10.1002/bse.1875

Oliveira, G. G. Indústria petroquímica e a gestão do meio ambiente. Organizações \& Sociedade, v. 6, p. 51-59, 1999. https://doi.org/10.1590/S1984-92301999000200005

Ometto, M. P.; Bulgacov, S.; May, M. R. The effectiveness of the strategists of corporate social responsibility. Organizações \& Sociedade, v. 22, p. 423-442, 2015. https://doi.org/10.1590/1984-9230747

Pena, R. P.; Queiroz, H.; Carvalho Neto, A.; Teodósio, A.; Dias, A. S.; Fernandes, T. Responsabilidade social empresarial e estratégia: um estudo sobre a gestão do público 
interno em duas empresas signatárias do global compact. Organizações \& Sociedade, v. 14, p. 81-98, 2007. https://doi.org/10.1590/S1984-92302007000100005

Porter, M. E. Estratégia competitiva: técnicas para análise de indústrias e da concorrência. Campus: Rio de Janeiro, 1986.

Porter, M. E. Toward a dynamic theory of strategy. Strategic Management Journal, v. 12, p. 95-117, 1991.

Porter, M. E.; Kramer, M. R. Strategy and society: The link between competitive advantage and corporate social responsibility. Harvard Business Review, v. 84, p. 78-92, 2006.

Quinn, J. B. Strategic change: “Logical incrementalism”. Sloan Management Review, v. 20, p. 7-21, 1978.

Ramos, A. G. A consciência crítica da realidade nacional: definição e descrição da redução sociológica. In: Ramos, A. G. A redução sociológica: introdução ao estudo da razão sociológica. 2. ed. Rio de Janeiro: Tempo Brasileiro, 1965.

Rodrigues, S. B.; Carrieri, A. P. A tradição anglo-saxônica nos estudos organizacionais brasileiros. Revista de Administração Contemporânea, v. 5, p. 81-102, 2001. https://doi.org/10.1590/S1415-65552001000500005

Ronda-Pupo, G. A.; Guerras-Martin, L. Á. Dynamics of the evolution of the strategy concept 1962-2008: A co-word analysis. Strategic Management Journal, v. 33, p. 162-188, 2011. https://doi.org/10.1002/smj.948

Salas-Zapata, W. A.; Ortiz-Muñoz, S. M. Analysis of meanings of the concept of $\begin{array}{lllll}\text { sustainability. Sustainable Development, } & \text { v. 27, p. 153-169, } 2019 .\end{array}$ https://doi.org/10.1002/sd.1885

Salas-Zapata, W. A.; Rios-Osorio, L. A.; Cardona-Arias, J. A. Methodological characteristics of sustainability science: A systematic review. Environment, Development and Sustainability, v. 19, p. 1127-1140, 2017. https://doi.org/10.1007/s10668-016-9801-z

Sanches, C. S. Gestão ambiental proativa. Revista de Administração de Empresas, v. 40, p. 76-87, 2000.

Scherrer, Y.; Daub, C.-H.; Burge, P. Toward integrating sustainability into business strategy.

Business Strategy and the Environment, v. 16, p. 459-460, 2007. https://doi.org/10.1002/bse.594

Sehnem, S.; Lukas, M. C.; Marques, P. D. Elaboração e aplicação dos indicadores de sustentabilidade em pequenas e médias empresas. Navus - Revista de Gestão e Tecnologia, v. 5, p. 22-41, 2015. https://doi.org/10.22279/navus.2015.v5n3.p22-41.225

Sehnem, S.; Pavão, Y. M. P.; Rossetto, A. M.; Leonardi, V. A. Recursos organizacionais em frigoríficos e sua relação com a implantação de estratégias voltadas à sustentabilidade ambiental: o caso do Grupo Marfrig Alimentos S.A. Revista Brasileira de Gestão de Negócios, v. 14, p. 193-215, 2012. https://doi.org/10.7819/rbgn.v14i43.978

Sousa Filho, J. M.; Wanderley, L. S. 0.; Gómez, C. P.; Farache, F. Strategic corporation social responsibility management for competitive advantage. Brazilian Administration Review, v. 7, p. 294-309, 2010. https://doi.org/10.1590/S1807-76922010000300006

Souza, M. T. S. Rumo à prática empresarial sustentável. Revista de Administração de Empresas, v. 33, p. 40-52, 1993. https://doi.org/10.1590/S0034-75901993000400005

Volpon, C. T.; Macedo-Soares, T. D. L. V. A. Alinhamento estratégico da responsabilidade socioambiental corporativa em empresas que atuam em redes de relacionamento: 
resultados de pesquisa na Petrobras. Revista de Administração Pública, v. 41, p. 391-418, 2007. https://doi.org/10.1590/S0034-76122007000300002

Wernerfelt, B. A resource-based view of the firm. Strategic Management Journal, v. 5, p. 171-180, 1984.

License information: This is an open-access article distributed under the terms of the Creative Commons Attribution License, which permits unrestricted use, distribution, and reproduction in any medium, provided the original work is properly cited. 